\title{
DINAMIKA PENGELOLAAN DAN PERTUMBUHAN USAHA KECIL PABRIK KERUPUK TAPIOKA "REJO" BLOTONGAN SALATIGA
}

\author{
Oleh \\ Samtono \\ Dosen Tetap STIEPARI Semarang
}

\begin{abstract}
Abstrak
Penelitian tentang Usaha Mikro, Kecil, dan Menengah bertujuan : Untuk mengetahui dan mendeskripsikan sikap dan perilaku usaha industri kecil serta model pengelolaan pengembangan industri kerupuk tapioka "REJO" di Blotongan; dan untuk mengetahui dan mendeskripsikan strategi atau cara-cara meningkatkan ketrampilan/kompetensi para karyawan yang sesuai dengan bidang tugas masing-masing; serta untuk mengetahui dan mendeskripsikan mengapa perusahaan lebih dominan untuk memilih tenaga kerja pada tetangganya/masyarakat sekitar perusahaan.

Pendekatan pada penelitian disini menggunakan pendekatan deskriptif kualitatif jenis penomenologis, dan teknik pengambilan sampel/nara sumber dengan teknik Purposive sampling artinya didalam memilih nara sumber harus memenuhi persyaratan atau kriteria tertentu, adapun yeng terpilih menjadi nara sumber sebanyak 10 orang yang meliputi: Pimpinan perusahaan, Bendahara perusahaan; sekretaris perusahaan, bagian pembuatan desain/bakalan; bagian pengeringan ; bagian penggorengan; bagian pensotiran; bagian pengepakkan; bagian pemasaran; dan bagian terakhir bagian serabutan, masing-masing bagian satu orang.

Hasil penelitian yang didapat adalah sebagai berikut: Pertama Sikap dan perilaku para karyawan yang lebih banyak diberi kepercayaan dari perusahaan dan para karyawannya menyatakan bahwa jenis pekerjaan yang dikerjakan dari awal sampai akhir proses pembuatan kerupuk relatif mudah dikerjakan dantidak memerlukan pemikiran yang sulit, lagi pula bekerjanya relatif penuh rasa kekeluargaan, kebersamaan dan perhatian dari perusahaan, serta relatif sejahtera, jadi relatif betah dan nyaman diperusahaan, dan model pengelolaannya lebih menekankan pada pendekatan kekeluargaan dan kebersamaan, atau sering disebut sebagai model yang konvensional/tradisional jadi tidak ada pimpinan dan tidak ada bawahan satu sama lain merasa sama dan menjadi satu. Kedua guna meningkatkan ketrampilan/kompetensi para karyawannya dengan teknik tutor sebaya, artinya kayawan yang sudah senior selalu mendampingi sekaligus menjadi pelatih yang yunior. Ketiga Perusahaan lebih dominan mengambil tenaga kerja/karyawannya dilingkungan tetangga dengan pertimbangan lebih hemat, efektif, praktis, efisien, dan memahami lebih dulu latar belakang dan karakter para karyawannya.
\end{abstract}

Kata Kunci : UMKM

Dinamika Pengelolaan Dan Pertumbuhan Usaha Kecil

Pabrik Kerupuk Tapioka "Rejo" Blotongan Salatiga. (Samtono) 


\section{PENDAHULUAN}

\section{Latar Belakang Masalah}

Usaha Mikro, Kecil, dan Menengah, ( UMKM ) mempunyai peranan stategis dalam pembangunan ekonomi nasional. UMKM berperan dalam pertumbuhan ekonomi dan penyerapan tenaga kerja. Selain itu juga berperan dalam pendistribusian hasil-hasil pembangunan. Keberadaan sektor Usaha Mikro, Keci,l dan Menengah, bukan hanya tempat penampungan sementara bagi para pekerja yang belum masuk ke sektor formal, tetapi sebagian besar berlokasi di pedesaan. Kejadian krisis ekonomi pada tahun 1998 sampai dengan tahun 2002 yang lampau, kiranya tidak berlebihan apa bila pengembangan sektor swasta difokuskan pada UMKM.

Sulistyastuti ( 2004 ) menyebutkan ada empat alasan yang menjelaskan posisi strategis UMKM di Indonesia. Pertama, UMKM tidak memerlukan modal yang besar sebagaimana perusahaan besar sehingga pembentukan perusahaan ini relatif mudah tidak sesulit usaha besar. Kedua, tenaga kerja yang diperlukan tidak menuntut pendidikan formal tertentu. Ketiga, sebagian besar berlokasi dipedesaan dan tidak memerlukan infrastruktur sebagaimana perusahaan besar. Keempat, UMKM terbukti memiliki ketahanan yang kuat ketika Indonesia dilanda krisis ekonomi. Kementrian Koperasi dan UMKM (2012) menyebutkan usaha mikro, keci,l menengah yang berkembang saat ini terbagi menjadi beberapa kategori, yaitu pertanian, peternakan, perikanan, kehutanan, listrik, gas, air bersih, perdagangan, hotel, restoran, jasa-jasa swasta, dan industri pengolahan salah satunya mencakup industri kreatif. Sektor industri kreatif diyakini mampu bertahan ketika berbagai sektor lain dilanda krisis keuangan global.

Pemerintah mulai melirik industri kreatif sebagai alternatif roda penggerak ekonomi yang akan terus berputar, industri kreatif meliputi subsektor yaitu industri makanan ringan, makanan kecil kas daerah, industri kerupuk baik yang dari bahan baku tepung terigu, tepung tapioka, udang maupun dari beras dan umbi-umbian, adapun khusus di Salatiga sudah relatif banyak produk-produk kas daerah seperti enting-enting gepuk, gethuk ketela pohon, gula kacang, abon, dendeng, dan jenis lainnya yang relatif mewarnai kekhasan dari Salatiga. Adapun sub sektor yang lain seperti: periklanan, arsitektur, pasar barang seni, kerajinan desain, busana, vidio film, dan fotografi, permainan interaktif, musik, seni pertunjukkan, percetakan dan 
penerbitan, layanan komputer dan pirnti lunak serta riset dengan pengembangannya. Pemerintah Indonesiapun mulai melihat bahwa berbagai subsektor dalam industri kreatif berpotensi untuk dikembangkan karena bangsa Indonesia mempunyai sumber daya insani kreatif dan warisan budaya yang kaya. Selain itu industri kreatif juga dapat memberikan kontribusi diberbagai aspek kehidupan.

Kementrian Perdagangan (2008) menyebutkan industri kreatif bagian tak terpisahkan dari ekonomi kreatif. Ekonomi kreatif dapat dikatakan sebagai transaksi penawaran dan yang bersumber dari pada kegiatan ekonomi yang digerakan oleh sektor industri yang disebut industri kreatif. Industri kreatif perlu dikembangkan di Indonesia karena memiliki peranan penting dalam pengembangan ekonomi negara dan daerah ( Departemen Perdagangan) Pertama, sektor industri kreatif memberikan kontribusi ekonomi yang positif dan signifikan seperti peningkatan lapangan pekerjaan, peningkatan ekspor, dan sumbangannya terhadap pertumbuhan ekonomi. Kedua menciptakan iklim ekonomi bisnis kreatif dan positif yang berdampak pada sektor riil. Ketiga Membangun citra dan identitas bangsa seperti taurisme, ikon nasional, membangun budaya, warisan budaya, dan nilai lokal. Keempat berbasis pada Sumber Daya yang terbarukan seperti ilmu pengetahuan dan peningkatan kreatifitas. Kelima, menciptakan inovasi dan kreatifitas yang merupakan keunggulan suatu bangsa. Keenam, dapat memberikan dampak sosial yang positif seperti peningkatan kualitas hidup dan toleransi sosial. Kota Salatiga merupakan bagian dari kota di Jawa Tengah memiliki budaya lokal yang berpotensi bagus untuk dikembangan seperti dikota-kota di Jawa Tengah lainnya , contoh seperti Kota Solo, Kota Pekalongan, Kota Semarang, Kota Kudus dan sebagainya yang sudah memiliki Brand Images sendiri tentang produk-produk daerah yang khas sampai menjadi komoditi ekpor. Disalatiga sebenarnya sudah mengejar seperti kota-kota lain di Jawa Tengah namun varians-nya yang juga perlu dikembangan. Mengingat Kota Salatiga sudah memiliki Peraturan Daerah Nomor : 10 Tahun 1993 dan Peraturan Daerah Nomor: 5 Tahun 1996. yang di dalamnya memuat Salatiga sebagai Kota Pendidikan, Kota Olah Raga, dan sebagai Kota Transit yang disebut sebagai “ TRI FUNGSI KOTA SALATIGA”. Disamping itu Salatiga juga sudah memiliki produk-produk unggulan seperti Abon sapi, Dhendheng, Enting-enting, Gula kacang, Bandeng asap, dan sebagainya yang sudah mencapai pasaran seluruh nusantara, bahkan seperti Abon sapi dan dhendheng 
sapi sudah menjadi produk unggulan khas daerah dan menjadi komoditi eksport. Namun produk-produk industri kreatif seperti Kerupuk Tapioka, Kerupuk Dele, Kerupuk Singkong, Krupuk Ubi-ubian, Kerupuk Udang, belum mendapat pasaran dan sambutan masyarakat itu sendiri seperti produk-produk unggulan tersebut diatas khususnya masyarakat di Kota Salatiga dan sekitarnya. Maka dipandang perlu dikaji mengapa belum bisa mencapai kualitas produk seperti yang sudah ada.

Kota Salatiga sebenarnya sangat produktif akan model-model dan jenis-jenis industri kreatif hasil produk masyarakat itu sendiri, baik yang bersifat hasil kerajinan tangan, hasil pertanian, buah-buahan, hasil anyam-anyaman bambu, maupunkayu, dan banyak ragamnya, sebagai contoh yang dijajakan ditepi jalan raya didesa Lopait dan Kesongo dekat pintu Gerbang masuk Kota Salatiga, kalau dari arah Semarang, maupun di Desa Tingkir Kota Salatiga bagian Timur. Hasil produk industri kreatif masyarakat Salatiga dan sekitarnya sebagai illustrasi, sebenarnya cukup menggembirakan sebagai aset pengembangan sumber daya masyarakat yang ada dan perlu dikembangkan sebagai bagian program pengembangan Usaha Mikro Kecil Menengah ( UMKM ) di Jawa Tengah Khususnya di Kota Salatiga. Pengambilan lokasi penelitian pada Industri Kerupuk Tapioka REJO didesa Blotongan Salatiga, dengan pertimbangan pabrik atau industri tersebut sudah berdiri selama 28 tahun dan tidak mengenal krisis, sungguhpun pemerintah pernah dilanda krisis paling parah pada tahun 1998, namun industri tersebut tetap kokoh tidak tergoyahkan dan dari waktu ke waktu semakin mantap, disamping itu yang paling prinsip adalah mampu menampung para tetangganya untuk bekerja dipabriknya sehingga menolong pemerintah didalam upaya menanggulangi pengangguran dan pertumbuhan ekonomi didesa Blotongan Salatiga.

\section{Rumusan Masalah Penelitian.}

1. Bagaimana model pengelolaan pengembangan industri kerupuk tapioka REJO di Desa Blotongan Salatiga?

2. Bagaimana strategi guna meningkatkan kompetensi karyawan atau ketrampilan khusus sesuai dengan cakupan tugas masing-masing.?

3. Mengapa perusahaan lebih dominan memilih tenaga kerja dari masyarakat sekitar industri/pabrik atau para tetangganya sendiri? 


\section{Manfaat Penelitian}

Kegiatan penelitian bermaksud mengungkap sikap dan perilaku bagi pelaku usaha industri kecil dan model Pengelolaan yang dilaksanakan pada perusahaan, serta dibalik kesuksesan pada perusahaan, dimana selama ini industri mampu berproduksi serta mampu bertahan yang tidak mengenal krisis, dan dari waktu ke waktu semakin mantap dan relatif berkembang dengan baik, banyak melibatkan tenaga kerja masyarakat sekitar industri, khususnya para tetangga yang tidak mensyaratkan pendidikan formal atau kompetensi khusus / ketrampilan khusus untuk menjadi karyawannya

\section{Tujuan Penelitian}

Penelitian dilakukan dengan tujuan sebagai berikut:

1. Untuk mengetahui dan mendeskripsikan sikap dan perilaku pelaku usaha industri kecil, dan model pengelolaan pengembangan industri Kerupuk Tapioka REJO Blotongan Salatiga

2. Untuk mengetahui dan mendeskripsikan strategi atau cara-cara meningkatkan ketrampilan khusus/kompetensi bagi para karyawan sesuai dengan cakupan tugas masing-masing

3. Untuk mengetahui dan mendeskripsikan mengapa perusahaan lebih dominan untuk mengambil tenaga kerja masyarakat sekitarnya atau tetangganya sendiri. 


\section{LANDASAN TEORI}

\section{Dasar Legalitas UMKM di Indonesia.}

1. Undang-Undang Republik Indonesia Nomor 20 Tahun 2008 Tentang Usaha Mikro,kecil, dan Menegah.

2. Peraturan Gubernur Jawa Tengah Nomor : 41 Tahun 2008, Tentang Kegiatan Pelatihan Koperasi dan Usaha Mikro Kecil dan Menengah, di Daerah Jawa Tengah.

3. Peraturan Daerah Kota Salatiga, Nomor : 10 Tahun 1993; Dan Peraturan Daerah Kota Salatiga Nomor: 5 Tahun 1996, Tentang Tri Fungsi Kota Salatiga.

\section{Teori Sikap dan Perilaku Pengelola UMKM.}

Teori sikap dan perilaku yang dikembangkan oleh Fishbein dan Ajzen's dalam Azwar (2007) teori yang terkenal dengan judul "Theory of Reasoned Action" dan sudah dimodifikasi oleh Malhotra dan Galleta. Mengembangkan model sikap dan perilaku seseorang baik secara sendiri-sendiri maupun secara berkelompok pada suatu organesasi seperti gambar model sebagai berikut :

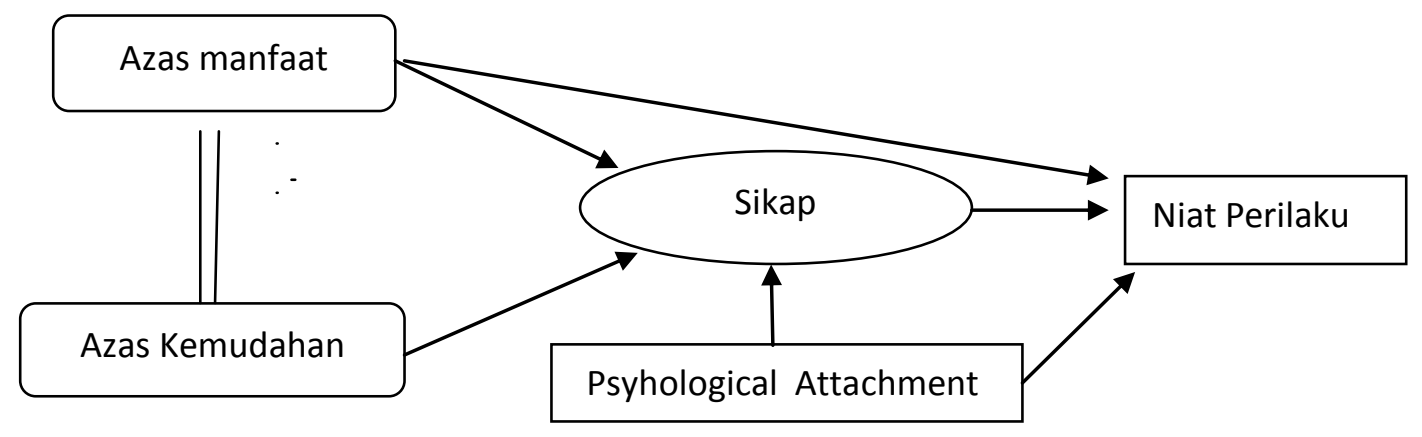

Gambar 1

Model Sikap dan Perilkau, Fiesbein dan Ajzen's

Yang dimodifikasi oleh Malhotra dan Galleta .

Dari gambar model tersebut di atas dijelaskan bahwa seseorang secara sendirisendiri maupun secara berkelompok pada suatu organisai akan bersikap dan berperilaku terhadap sesuatu apabila adanya unsur-unsur kemudahan, begitu seseorang baik secara sendiri-sendiri atau secara berkelompok pada suatu organisai 
akan bersikap dan berperilaku terhadap sesuatu apabila adanya unsur-unsur kemanfaatannya. Akan tetapi sebaliknya manakala seseorang baik secara sendirisendiri maupun secara berkelompok pada suatu organisasi tidak akan bersikap dan berperilaku jika tidak adanya unsur-unssur kemudahan dan kemanfaatan baik bagi dirinya sendiri maupun untuk kelompoknya atau untuk organisasinya.

\section{Manajemen Produksi}

Menurut J.F.Stoner dalam Napitupulu (2001) memberikan pengertian, Manajemen suatu rangkaiaan aktifitas (4 fungsi) yan diarahkan pada sumber daya organisasi untuk tujuan organisasi secara efektif dan efisien.

Bidang produksi menentukan keberhasilan industri/perusahaan, aktivitas bidang pemasaran dan produksi makin lancar bila didukung bidangkeuangan dan bidang-bidang lain yang berkaitan. Sedangkan manajemen produksi menurut O’Dukker dalam Sukarna (2011), Tingkat produktifitas yang umum digunakan adalah jumlah produk yang dihasilkan atau jumlah layanan yang diberikan perunit masukan atau dapat pula dalam bentuk penurunan biaya yang diharapkan, mengurangi jumlah produk rusak,mengurangi keluhan konsumen, menekan jam lembur, dan sebagainya

\section{METODE PENELITIAN}

Dalam penelitian di sini digunakan pendekatan penelitian Deskriptif Kualitatif jenis fenomenologis artinya seorang peneliti melakukan penelitian didasarkan adanya fenomena-fenomena yang terjadi pada obyek penelitian, adapun teknik pengambilan sampel atau nara sumber/informan dengan teknik purposive sampling, artinya didalam menentukan nara sumber/informan didasarkan atas syarat-syarat tertentu atau yang telah memenuhi kriteria tertentu yang telah ditetapkan sebelumnya . Adapun teknik pengambilan data dengan teknik wawancara mendalam atau sering disebut dengan Depth Interview dan analisis data digunakan model Miles dan Humberman.

\section{HASIL PENELITIAN DAN PEMBAHASAN}

\section{Deskripsi Obyek Penelitian}

Prabrik Kerupuk Tapioka ' REJO ' yang beralamat di Desa Blotogan RT. 01, RW. V, Kecamatan Sidorejo Salatiga. Secara historis pabrik kerupuk tapioka yang dimiliki oleh bapak Haji Machmud Fathoni B.Sc. berangkat dari modal yang sangat sederhana dan kondisinya waktu itu sangat memprihatinkan sekali, mengingat semula 
bapak Fathoni adalah berprofesi seorang guru SMA Swasta pengampu mata Pelajaran Bahasa Inggris pada SMA Muhammadiyah di Kota Purwadadi yang sudah ditekuni selama 8 tahun. Namun pada kenyataannya pada tahun 1990-an gaji guru waktu itu tidak memcukupi untuk membiayai hidup satu istri dengan satu anak. Akhirnya bapak Fathoni mengambil suatu keputusan untuk mengakiri profesi gurunya dan berpindah untuk mengawali profesi barunya yaitu merintis usaha kecil-kecilan mencoba merintis untuk membuat kerupuk dari tepung tapioka atau saripati ketela pohon sampai sekarang.

\section{Dinamika Pertumbuhan.}

Pabrik Kerupuk tepung tapioka “ REJO “ pertama kali didirikan pada awal Januari 1990, pertama mendirikan pabrik kerupuk dengan modal semangat dan pasrah pada Tuhan Maha Pengasih semata, setelah pidah rumah untuk usaha dari Purwadadi ke Salatiga Bapak H M Fathoni hanya mampu menyewa rumah kecil di desa Prampelan Blotongan Salatiga, dimana rumah tersebut adalah milik bapak Kepala Desa Blotongan yaitu Bapak Drs. H. Sukirno. Pertama kali masuk didesa blotongan hanya bermodal bahan baku untuk dibuat kerupuk yang relatif sangat sedikit dan peralatan sederhana untuk memproses pembuatan kerupuk dengan alat-alat sederhana dan tenaga kerja 3 orang ditambah Bapak Fathoni sendiri. Dari tahun demi tahun perjalanannya tidak seperti yang diharapkan kadang -kadang jalan, kadang-kadang harus tutup karena kehabisan modal, dan kala itu tidak mudah untuk mencarai pinjaman modal, tidak seperti sekarang pemerintah telah memberikan Kemudahan bagi usaha mikro, kecil, dan menengah untuk mendapatkan pinjaman modal dengan bunga rendah. Puncak paling kritis dan parah sekitar tahun 1997 sampai dengan tahun 1998 kondisi perekonomian didalam negeri sangan parah yang dibarengi dengan jatuhnya pemerintahan Orde Baru yang berdampak pada lengsernya Bapak Presiden RI ke 2, Almarhun Bapak Jendral Besar Suharto. Seiring dengan berjalannya waktu akhirnya Bapak HM Fathoni selalu memperhatikan perjalanan usahanya, mengingat berkali-kali ditempa badai atau cobaan krisis ekonomi didalam negeri akhirnya mengambil sikap dengan penuh kehati-hatian dalam mengelola perusahaannya, artinya tidak ingin mencari untung atau laba yang besar atau banyak, yang penting usahanya jalan dan sekaligus membantu masyarakat sekitar untuk membantu menjalankan usahanya dengan cara direkrut menjadi karyawan. Memang jika dilihat 
proses pembuatannya relatif panjang dan melelahkan, namun keuntungannya relatif kecil. Pemilik perusahaan selalu bersyukur sungguhpun mengambil keuntungan hanya sedkit alhamdulillah usahanya bisa berjalan dengan lancar dan baik, artinya sejak krisis yang paling parah ditahun 1997 sampai dengan 1998. Namun sekarang sudah tidak lagi mengalami krisis seperti tahun-tahun lalu, dengan prinsip Alon-alon waton klakon lan sethithik nanging nglethik ( jawa ). Sampai akhir tahun 2015 perusahaan tersebut telah merekrut tenaga kerja sebanyak 57 orang, meliputi : pembuatan bakalan ( kerupuk mentah ) 8 orang; Bagian open kerupuk mentah 4 orang; proses pengeringan 6 orang; bagian penjemuran 6 orang; bagian pensotiran 5 orang; bagian penggorengan 5 0rang; bagian pengepakkan 4 orang; bagian serabutan 5 orang; dan bagian pemasaran sebanyak 14 0rang. Dan jumlah aset seluruhnya baik barang yang bergerak ataupun yang tidak bergerak ditaksir oleh Bapak HM Fatoni kurang lebih sekitar Rp4.500.000.000,00 ( empat milyar lima ratus juta rupiah )

\section{Hasil Analisis Data}

1. Sikap dan perilaku pengusaha industri kecil saat ini yang dilakukan hanya sekedar mengikuti keadaan atau situasi yang ada didalam negeri ini, mengingat semua itu juga sangat tergantung situasi dan kodisi perekonomian dunia dan kondisi politik dalam negeri yang sedang berjalan saat ini. Kita tidak bisa bermain sendiri, sebagai usaha kecil sangat rentan dengan kebangkrutan atau kegagalan mengingat hanya bermodalkan semangat dan kehati-hatian dalam mengelola semuanya. Dilihat dari jenis usaha yang ditekuni memang memiliki kompetisi yang sangat ketat dan berat disertai dengan banyaknya jenis-jenis kerupuk yang beredar ditengah-tengah masyaraakat serta beragamnya akan tuntutan masyarakat akan kerupuk sebagai menu kebutuhan masyarakat sebagai bagian dari kebutuhan yang dikonsumsi oleh masyaraakat sehari-harinya. Masyarakat selalu manuntut harga kerupuk yang murah, rasanya gurih dan enak sebagai pendamping lauk pauk makan sehari-hari. Kerupuk sebagai kebutuhan seluruh masyarakat yang tidak mengenal lapisan masyarakat dan tidak mengenal usia, semua masyarakat di Indoesia khususnya Jawa pasti tidak akan meninggalkan pendamping lauk pauk dikala makan. Usaha kecil yang ditekuni oleh pemilik perusahaan sampai sekarang, menggunakan beberapa prinsip antara lain, Prinsip Pertama, dimana ada orang jawa pasti akan membutuhkan kerupuk tapioka yang terbuat dari 
saripati ketela pohon yang lazim disebut singkong. Inilah yang dijadikan falsafah oleh perusahaan, adapun alasan lain dari pemilik perusahaan bahwa proses dalam memproduksi kerupuk tidak sulit seperti industri kecil jenis makanan selain kerupuk, memang prosesnya panjang dan melelahkan didalam memproduksi kerupuk namun proses pembuatan mudah dijalani hampir semua orang/karyawannya pasti bisa menjalankannya. Prinsip kedua perusahaan dikelola dengan pendekatan rasa kekeluargaan, artinya didalam perusahaan tidak ada Bos, dan tidak ada bawahan, semuanya merasa menjadi satu untuk bertanggung jawab akan kelangsungan perusahaan. Suksesnya perusahaan berarti suksesnya semua personil/karyawan pada perusahaan, dan gagalnya perusahaan berarti kegagalan personil/karyawan. Prinsip Ketiga, semua personil/karyawan bertanggung jawab dengan sebaik-baiknya akan tugasnya masing-masing dan semua sebagai bos dan semuanya sebagai pengawas atau supervisor, dan semua untuk selalu menghasilkan produk yang terbaik agar bisa diterima dan dibutuhkan oleh konsumen, dan konsumen selalu dibuat untuk menjadikan produk menjadi bagian dari kehidupan sehari-harinya, dan selalu dibutuhkan dan dicari, karena sudah menjadi bagian dari kehidupan yang tidak bisa dipisahkan. Model pendekatan dan pengelolaan yang telah dijalankan oleh perusahaan pada prinsipnya mengarah dan mendasarkan pada konsep "Total Quality Management" atau lazim dinamakan dengan Manajemen terpadu. Artinya dari masing-masing sub bagian dari struktur organesasi yang dijalankan satu sama lain saling melengkapi, saling memperbaiki, saling menilai, saling mengawasi, dan semuanya saling membuat suatu produk menjadi yang terbaik, dengan yang terbaik berarti pelanggan akan mendapatkan kepuasan, yaitu sesuatu yang diminta atau diharapkan.

2. Strategi peningkatan Kompetensi dan ketrampilan karyawan sesuai dengan cakupan tugas masing-masing, perusahaan selalu memberikan kepercayaan penuh pada personil/karyawan sesuai dengan job dan tugasnya masing-masing. Karyawan yang sudah senior atau berpengalaman selalu memberikan arahan dan pelatihanpelatihan secukupnya agar yang bersangkutan bisa mandiri dan bekerja sesuai tugasnya dengan sebaik-baiknya. Senior selalu membantu yang masih yunior selalu menawarkan apakah masih perlu bimbingan atau tuntunan pada yang masih memerlukan. Perusahaan selalu menekankan setiap personil/karyawan harus bisa 
menjalankan tugas dan tanggung jawab yang sebaik-baiknya demi menjaga kualitas produk terhadap pelanggan atau coustomers. Perusahaan menerapkan kebijakan dengan pertimbangan dan penilaian bahwa, dengan cara seperti tersebut sebenarnya sudah menjadi program secara terencana dari perusahaan sekaligus sebagai bentuk dalam memberikan pelatihan dan ketrampilan yang selama ini dilakukan dan dinilai sangat efektif dan efisien sekali, tidak memerlukan waktu yang lama, praktis dan sistematis, kesalahan dan kekurangan bisa langsung ditemukan dan langsung pula dibetulkan saat itu pula. Pada dasarnya prinsip ini merupakan konsep peningkatan kompetensi dan ketrampilan personil yang lazim dinamakan "Skill competence". Dengan memiliki personil/karyawan yang kompeten dan trampil berarti perusahaan memiliki aset dan modal Sumber Daya Manusia ( SDM ) yang penting sekali untuk menjaga dan mengembangkan perusahaan kedepan. Kualitas SDM yang berkualitas dengan sendirinya juga akan menjaga kualitas poduk dari karyawannya. Maka langkah yang ditempuh dari perusahaan sebagai langkah untuk menuju "Quality Assurance" artinya konsep untuk menjaga penjaminan mutu produk atau kualitas produk yang telah dipasarkan pada konsumen/masyarakat telah terjamin akan kualitasnya dan tidak diragukan lagi oleh konsumen/masyarakat, baik rasanya, kesehatannya, kebersihannya, maupun kemanfaatannya bagi kesehatan tubuh manusia pada umumnya.

3. Perusahaan memilih tenaga kerja dilingkungan perusahaan/tetanga.

Bertetangga jika dibangun komunikasi yang baik dan penuh rasa kebersamaan dan persaudaraan bisa dipastikan menjadi sumber kekuatan yang luarbiasa untuk menggapai kesuksesan suatu organisasi atau perusahaan. Pemilik perusahaan mempunyai keyakinan, bahwa merekrut tenaga kerja tetangganya sendiri lebih banyak menolong dan berbuat sesuatu lebih banyak kearah sosialnya. Sudah menjadi komitmennya dengan keluarga bahwa apapun yang terjadi hidup didesa apalagi ditengah-tengah perkampungan yang padat penduduknya dan mayoritas masyarakat sekitarnya memiliki pekerjaan yang tidak tetap alias serabutan, kadang-kadang bekerja, kadang-kadang tidak bekerja, pada hal keluarganya tetap harus makan sehari tiga kali, ditambah biaya sekolah anak-anaknya dan kegiatan sosial dimasyarakat harus berjalan sebagai mana kebiasaan yang sudah berjalan. 
Melihat kondisi seperti itu pemilik perusahaan akhirnya lebih berfikir kritis dan berfikir jauh kedepan, dan akhirnya diambil suatu kesimpulan bahwa nantinya akan tinggal dikampung bersama anak istrinya sampai akhir hayatnya, dan selama ini sudah berjalam kurang lebih 26 tahun tinggal dikampung yang ditempati selama ini sudah merasa nyaman, tentram dan penuh rasa kebersanaan dam persaudaraan dengan para tetangganya yang sekaligus menjadi karyawan perusahaannya. Ada beberapa pertimbangan untuk mengambil tenaga kerja dilingkungan tetanganya sendiri. Pertama, Mengetahui secara persis perilaku dan karakter personal yang dipilih menjadi karyawanya baik dirinya sendiri maupun keluarganya beserta latar belakang yang dimilikinya. Kedua, Tidak memerlukan biaya yang besar guna menyeleksi dan memilih tenaga kerjanya. Ketiga, Sejak awal sudah teramati kecakapan dan ketrampilan yang dimiliki calon tenaga kerja serta tingkat kejujuran dan kesetiaan calon tenaga kerja yang akan dipilih, Keempat, Kualitas ibadahnya dalam kehidupan sehari-hari juga sudah menjadi catatan tersendiri, Kelima, Kualitas akademis dan kualifikasi pendidikan juga sudah diketahui, sungguhpun tidak menjadi syarat yang prinsip, Keenam, Kualitas kerjasama dan kegiatan sosial ditengah-tengah masyarakat, Ketujuh, Sikap loyalitas dan integritas serta rasa memiliki pada perusahaan mudah terbaca, Kedelapan, Manakala ada problem atau konflik relatif mudah terselesaikan karena tetangga yang sehari-hari selalu berkomunikasi, Kesembilan, manakala ada kesalahan dalam perusahaan dan atau yang berkaitan dengan pekerjaan diperusahaan para tetanga ikut bertanggung jawab untuk membantu menyelesaikan dengan baik dan tuntas, Kesepuluh, Semua karyawan harus bertanggng jawab akan keberlangsungan perusahaan baik buruknya perusahaan sangat tergantung pada semua karyawan mulai diangkat menjadi karyawan sudah ditanamkan rasa untuk memiliki perusahaan atau lazim disebut sebagai “ Sense of belonging " sungguhpun tidak dibuka penjualan saham bagi karyawan atau ke publik.

\section{Karakteristik Pengusaha UKM}

Drucker dalam Hendrani dkk (2008), mengatakan bahw definisi entrepreneur sebagai seseorang yang membangun usahanya sendiri dari usaha kecil adalah kurang memadai. Drucker mendifinisikan sebagai seseorang yang mencari dan 
merespons perubahan dan memandang perusahaan sebagai suatu kesempatan. Lebih jauh, Barrow (1993) menyebutkan beberapa kharakteristik pengusaha UKM yang sukses sebagai berikut :

1. Komitmen total dan kerja keras

Pengusaha UKM pada umumnya mempunyai rasa percaya diri yang tinggi terhadap ide bisnisnya, bekerja labih dari 8 jam perhari dan biasanya juga melibatkan anggota keluarga untuk memikul tanggung jawab dan mencapai sukses bersama.

2. Menerima kondisi ketidak pastian

Tidak seperti perusahaan besar yang cenderung menunda decision making sampai semua fakta yang dibutuhkan diketahui, pengusaha kecil berani membuat keputusan dan menanggung resikonya dengan beroperasi dalam kondisi yang tidak ada kepastian dimana data dan informasi yang ada belum/tidak sepenuhnya lengkap untuk menunjang decision making yang optimal.

3. Disiplin tinggi

Pengusaha kecil harus disiplin dalam membedakan cash dan profit agar tidak cepat tergoda menikmati profit, dalam arti konsumtif untuk memenuhi dan memuaskan kebutuhan dan keinginan pribadi.

4. Mempunyai sifat seorang penemu/originator

Menciptakan inovasi baru/memodifikasi produk lama miliknya/produk pesaing yang sudah ada, memasarkan dan mengelola sendiri pendapatan dan pengeluarannya.

5. Mempunyai sifat seorang perencana dan organisatoris/planner dan organizer Berawal dari gagasan/ide yang muncul, pengusaha kecil kemudian membuat tujuan (result oriented) dan selanjutnya mencari cara-cara untuk mencapainya. 
UMKM sering juga didefinisikan berdasarkan nilai penjualan dan nilai aset, menurut Undang-Undang Republik Indonesia Nomor 20 Tahun 2008 Tentang Usaha Mikro, Kecil, dan Menengah seperti pada kriteria sebagai berikut :

1. Usaha Mikro, memiliki kekayaan bersih Rp 50.000.000,00 ( lima puluh juta rupiah ) tidak termasuk tanah dan bangunan tempat usaha; atau memiliki hasil penjualan tahunan paling banyak Rp 300.000.000,00 ( tiga ratus juta rupiah ).

2. Usaha Kecil, memiliki kekayaan bersih lebih dari Rp 50.000.000,00 ( lima puluh juta ) sampai dengan paling banyak Rp 500.000.000,00 ( lima ratus juta rupiah ) tidak tidak termasuk tanah dan bangunan tempat usaha; atau memiliki hasil penjualan tahunan lebih dari Rp 300.000.000.,00 ( tiga ratus juta rupiah ) sampai dengan paling banyak Rp2.500.000.000,00 ( dua milyar lima ratus juta rupiah )

3. Usaha Menegah, memiliki kekayaan bersih lebih dari Rp 500.000.000,00 lima ratus juta rupiah ) sampai dengan paling banyak Rp 10.000.000.000,00 ( sepuluh milyar rupiah ) tidak termasuk tanah dan bangunan tempat usaha; atau memiliki hasil penjualan tahunan lebih dari Rp 2.500.000.000,00 ( dua milyar lima ratus juta rupiah ) sampai dengan paling banyak Rp 50.000.000.000,00 ( lima puluh milyar rupiah )

\section{SIMPULAN DAN SARAN}

Atas dasar beberapa deskripsi temuan hasil penelitian seperti yang tersebut di atas akhirnya dapat disimpulkan sebagai berikut :

\section{Simpulan}

1. Pertumbuhan dan perkembangan industri pabrik kerupuk tepung Tapioka " REJO “ yang berada didesa Blotongan Kecamatan Sidorejo Salatiga berdasarkan beberapa kriteria dari Undang-Undang Republik Indonesia Nomor : 20 Tahun 2008, Tentang Usaha Mikro Kecil dan Menengah termasuk kategori Usaha Kecil, artinya ada perubahan pertumbuhan dan perkembangan selama dalam perjalanan selama 26 tahun untuk membangun usahanya yaitu Industri Pabrik Kerupuk Tapioka yang diberi nama "REJO" Yang dalam bahasa jawa artinya menjadi ramai atau jaya untuk menuju sukses. 
2. Model pengelolaan yang dijalankan oleh perusahaan, menggunakan model kekerabatan dan kekeluargaan, artinya perusahaan dijalankan masih mengunakan pola-pola manajemen yang konvensional atau tradisional, dan tidak jelasnya struktur organisasi perusahaan berjalan atas dasar kepercayaan semua karyawan yang ada. Artinya tidak ada Pimpinan dan tidak ada bawahan, lebih mengedepankan kebersamaan dan kegotong royongan, artinya semua sebagai karyawan dan semua sebagai supervisor dan setiap saat karyawan selalu diputar tugasnya, maka semua harus siap untuk mendapatkan tugas yang baru.

3. Peningkatan kompetensi dan ketrampilan para karyawan dilakukan dengan model "TUTOR SEBAYA “ artinya karyawaan yang sudah senior diberi tugas dan tanggung jawab untuk membina, membimbing, dan melatih karyawan-karyawan yang yunior dengan pertimbangan lebih praktis dan sederhana serta effisien dan effektif, tidak perlu mengeluarkan biaya untuk melatih secara khusus. Dibalik itu semua selama ini pemerintah belum turun tangan termasuk juga tidak memberikan perhatian terhadap perusahaanperusahaan kecil apa lagi mengarah untuk peningkatan kompetensi dan ketrampilan guna menuju Sumber Daya Manusia yang lebih berkualitas, sehingga produk yang dihasilkan juga belum mampu berkompetisi dilingkungan lokal, dan masih mengandalkan situasi alami yaitu kondisi perekonmian yang ada dan yang berjalan saat itu saja. Artinya sustainability atau keberlanjutan pemasaran produk belum terjamin keajegan atau keberlangsungannya.

4. Perusahaan lebih dominan mengambil tenaga kerja tetangga atau keluarga dekatnya dengan pertimbangan, dengan tetangga perusahaan mengetahui secara persis akan latar belakang kualitas dan karakter atau kepribadian para karyawannya, mengingat dalam kegiatan sehari-hari selalu berinteraksi baik dilingkungan perusahaan maupun dilingkungan kemasyarakatan, dengan cara seperti itu mana kala ada konflik yang berkaitannya dengan tugas perusahaan suka tida suka harus saling menyadari untuk segera diselesaikan dengan sebaik-baiknya dan saling menjaga dan saling bertanggung jawab 
akan keberlangsungan perusahaan yang selama ini menjadi tumpuhan hidup bagi keluarganya.

\section{Saran}

1. Perusahaan sudah saatnya memanfaatkan perhatian dari pemerintah khususnya bantuan modal untuk mengembangkan usahanya agar lebih produktif dan berdaya saing yang lebih baik atau unggul, guna keberlangsungan usahanya, seperti bantuan-bantuan modal dari bank dengan bunga rendah.

2. Perusahaan perlu ada terobosan baru untuk meningkatkan produk-produk yang berkualitas agar memiliki daya saing dan bisa menembus pasaran keluar kota, atau tidak untuk memasok dalam kota saja. Termasuk menggunakan alat-alat permesinan dan teknologi yang sudah ada saat ini guna untuk meningkatkan efisiensi dan produktifitas kerja .

3. Pemerintah daerah harus turun tangan membantu para pengusahapengusaha mikro, kecil, dan menengah ( Khususnya Dinas Koperasi dan UMKM ) untuk membantu para pengusaha-pengusha kecil untuk diberi penyuluhan-penyuluhan atau diikutsertakan pelatihan-pelatihan seperlunya guna meningkatkan ketrampilan dan kompetensinya, dengan harapan kedepan mampu menghasilkan produk-produk yang berkualitas dan berdaya saing yang tinggi mampu berkompetisi dengan produk-produk dari daerah lain. 


\section{DAFTAR PUSTAKA}

Abas Sunarya, dkk 2011, “Kewirausaan " Pnbt : ANDI, Yogyakarta

Azwar Saifudin, 2007, “ Sikap manusia Teori dan Pengukurannya ”, Edisi ke-2, Pustaka Pelajar; Yogyakarta

Chuck William, Penerjemah: Sabarudin Napitulu, 2011 “ Manajemen "Salemba Empat, Jakarta

Kementrian Negara Koperasi dan Usaha Kecildan Menengah Republik Indonesia, 2007 “ Materi Pelatihan : “ Diklat Koperasi Bagi Guru” Jakarta

Peraturan Daerah Nomor: 10 Tahun 1993, dan Peraturan Daerah Nomor : 5 Tahun 1996 Tentang “ Tri Fuungsi Kota Salatiga “ 2005, Sekretariat Pemda Kota Salatiga.

Peraturan Gubernur Jawa Tengah, Nomor: 41 Tahun 2008, Tentang “ Pemberdayaan Koperasi dan UMKM di Jawa Tengah", 2008, Dinas Koperasi Jawa Tengah, Semarang

Sukarna, 2011, “Dasar-Dasar Manajemen,” CV Mandar Maju; Bandung

Suryana, 2013, “Kewirausahaan, Kiat dan Proses Menuju Sukses “ Pnbt; Salemba Empat, Bandung

Undang-Undang Republik Indonesia Nomor 20 Tahun 2008, Tentang “Usaha Mikro, Kecil dan Menengah" 2008, Lembaran Negara RI Nomor: 4866, Jakarta. 